\title{
Müslüman Kelamında Haberin Bilgi Değeri
}

\author{
MUSTAFA BOZKURT \\ Dr., İNÖNÜ Ü. İLAHIYAT FAKÜLTESI \\ e-posta: mbozkurt@inonu.edu.tr.
}

\begin{abstract}
The Epistemic Value of Hearsay in Muslim Theology. In this study, we deal with the reasons of why Muslim theologians have accepted the epistemic value of "hearsay"(khabar) in their doctrine of knowledge. As an evidential source of knowledge, "hearsay", which is not a separate source of knowledge in philosophical traditions, has been seen as an independent and significant source of knowledge among Muslim theologians. Muslim theologians seem to have entertained an all-inclusive, none-deductive, methodology in the cognitive field. In this regard, Muslim theologians consider "the authentic hearsay" as the most reliable source of knowledge. The authentic hearsay is categorized under two categories: 1.mutevatir hearsay, which is based on the testimony of a group of people that cannot be thought to be lying; 2 . the direct message of The Prophet.
\end{abstract}

\section{key words}

Hearsay, khabar, kalam, sourc of knowledge, certain knowledge, epistemologic value, Muslim theology.

\section{Giriş}

Felsefî gelenekte bilgi teorileri incelenirken bilgi elde etme vasıtaları olarak daha doğrusu bilginin kaynağ ${ }^{1}$ olarak hep "akıl" ve "duyular" üzerinde durulmuş. Felsefi oluşumlar akıl ve duyuya verdiği öncelik açısından rasyonalizm, empirizm vs. isimlendirilmişlerdir. ${ }^{2}$ Bu felsefî gelenek gerek Yu-

1 Burada bilgi kaynağı ile kastedilen insan bilgisinin kaynaklarıdır. Tüm varlıkların bilgi kayna$\breve{g}_{1}$ kastedilmemektedir.

2 Bk. W. K. C. Gutrie, "Illkçă̆ Felsefesi Tarihi" (Kazimierz Adjukiwicz, Felsefeye Giriş trc. Ahmet Cevizci) Ankara ts. s.34 -47; Nihat Keklik, Felsefenin Ilkeleri, Ankara 1976, s.101 vd. 
nan Felsefesinde, ${ }^{3}$ gerek İslam Felsefesinde ${ }^{4}$ ve gerekse günümüz Batı Felsefesinde ${ }^{5}$ devam ettirilmiştir.

Müslüman kelamcılar da bilgi teorisi ile ilgilenmișlerdir. Kelam kitaplarının ilk bölümleri genellikle "bilgi teorisi" konularına ayrılmıştır. ${ }^{6}$ Kelamcılar özellikle bilginin kaynakları konusunda "haber"i ayrı bir kaynak olarak ele almaları ile dikkat çekmişlerdir. Bilgi elde etmenin yolları konusunda bilgi teorisine önemli bir açllım getirmişlerdir. Haberin bilgi kaynağ 1 oluşunda Müslüman kelamcılar arasında pek ihtilaf yoktur fakat bilgi teorisini işlerken kullandıkları yöntem konusunda bazı farklılıkların olduğu görülmektedir.

Mâturîdî çizgide yer alan kelamcılar bilgi teorisini işledikleri kelam kitaplarında bilgi elde etmenin vasıtaları olarak duyu ve aklın yanında üçüncü bir kaynak olarak "haber"i ele alırlar ve incelerler." Haber konusunda

3 H. Krings / H.M. Baumgartner, "Bilgi Kuramı Tarihçesi," (Günümüzde Felsefe Disiplinleri, trc. Doğan Özlem), İstanbul 1997, s.206.

4 Her ne kadar bilginin kaynağı akıl ve duyu şeklinde ele alsalar da, İslam Filozofları akıl ve duyunun yanına vahyi de ayrı bir bilgi kaynağı olarak alırlar. Bu bilgi kaynağını vahiy ile sınırlandırırlar. Bk. İbrahim Hakkı Aydın, Fârâbî'de Bilgi Teorisi, İstanbul 2003, s.140-151; Hidayet Peker, İbn Sina'nın Epistemolojisi, Bursa 2000, s.143; Hüseyin Sarıŏlu, İbn Rüşd Felsefesi, İstanbul 2003 (Klasik Yayınları) s.115; Müslüman kelamcılar ise burada vahyi de içerisine alan "haber" kavramını kullanırlar. Bilginin kaynağını bu şekilde daha geniş tutarlar.

5 Bk. A. Kadir Çüçen, Bilgi Felsefesi, Bursa 2001, s.60-64; Nicolai Hartmann, Ontolojinin Işı̆̆ında Bilgi, (trc. Harun Tepe) Ankara 1998, s.14 vd; Fritz Heinemann, "Bilgi Kuramı" (Günümüzde Felsefe Disiplinleri, trc. Doğan Özlem), İstanbul 1997, s.91 vd.

6 Bk. Mâturîdî, Kitâbü't-Tevhit,(thk. Bekir Topaloğlu-Muhammed Aruçi), Ankara 2003 s.1121; Ebu'l-Muin en-Nesefî, , Tabsiratü'l-Edille (thk.Hüseyin Atay) Ankara 1993, I/9-34; Ebu'lMealî el-Cüveynî, Kitabü'l-İ́şad, Beyrut 1995, s.7-12; eş-Şamil fi Usuli'd-Din, Beyrut 1999, s.523; Nureddin Sâbûnî, el-Bidaye fi Usuli'd-Din, (thk. Bekir Topaloğlu), DİB. Yay. Ankara 1991, s.16-19; Ebu Yusr Muhammed el-Pezdevi, Ehl-i Sünnet Akaidi (trc. Şerafeddin Gölcük) İstanbul 1980, s.7-16; Fahreddin Râzî, el-Mebahisü'l-Meşrikıyye, (thk. Muhammed Mu'tasım Billah el-Bağdadî), Beyrut 1990, I/437-501; Muhassalu Efkâri'l-Mütekaddimûn ve'l-Müteahhirûn Mine'l-Hükemâ ve'l-Mütekellimîn, (tah. Semih Dugaym) Beyrut 1992, s.25-37; el-Mülahhas fi'l-Mantık ve'l-Hikme, Süleymaniye Ktp., Damat İbrahim Paşa,, No:827 vr.120a-132a; Seyfeddin Âmidî, Ebkâru'l-Efkâr fi Usûli'd-Din (thk. Ahmed Ferid Müzeydî) Daru'l-Kütübü'l-İlmiye, Beyrut 2003, I/15-138.

7 Bilgi teorisini sistemli bir şekilde ele alan ilk kelamcının Mâturîdî olduğu söylenmektedir. Mâturîdî’nin bilgi teorisinin temelinde doğru bilginin kaynağı olarak akıl, duylar ve haber yer alır. Mâturîdî’nin bilgi sistemi bu üç temel üzerine kurulmuştur. Mâturîdî’nin kendi ifadeleri, bu üç ayrı kaynağın verdiği bilgilerin diğer kaynaklar tarafından verilemeyeceği şeklindedir. Böylece Mâturîdî’nin bilgi anlayışı kaynaklar açısından çoğulcu bir bilgi anlayışıdır. Onun bilgi anlayışını bu kaynaklardan herhangi birine indirmek Mâturîdî’nin sistemini bozmak olur. Son dönem bazı çalışmalarda onun bilgi anlayışının temel dayanakları göz ardı edilerek Mâturîdî'nin akılcı/rasyonalist bir kelamcı olduğu vurgulanmaktadır. Bu indirgemeci söylemin Mâturîdî için bir haksızlık olacağı söylenebilir. Aklı ve akıl ilkelerini kullanmış olması onun "akılcı" bir düşünür olarak değerlendirilmesini gerektirmez. Çünkü o hem duyuların hem de haberin kesin ve güvenilir bilgi vereceği görüşündedir. Kısaca bilgi sisteminin temellerinde üçlü bir kaynağı 
bazı tasnifler yaparak kesin ve güvenilir bilgi veren haber türünden bahsederler. ${ }^{8}$ Eş'arî gelenekten gelen ve bilhassa memzuc -felsefe-kelam ilişkilerinin yoğun işlendiği- dönemin bazı kelamcıları "haber"in ayrı bir bilgi kaynağı olduğunu söylemekle beraber, yöntem olarak haberin bilgi kaynağ 1 oluşunu kelama dair yazdıkları kitaplarında pek işlememiş̧lerdir. Kelam kitaplarında genellikle bilginin kaynağ durmuşlardır. ${ }^{9}$ Daha ziyade "usûl-ü fikıh" içerikli kitaplarında "haber" konusunu genişçe ele almışlar ve "doğru haber" kategorisine giren haber türlerinin kesin bilgi ifade edeceğini belirtmişlerdir. ${ }^{10}$

Bu makalede haberin ne olduğu ve kelamcilar tarafından ${ }^{11}$ niçin öncelendiği üzerinde durulacaktır. Ayrıca Kelamcıların kesin bilginin kaynağı olarak hangi tür haberi temel aldıkları tartışılacaktır.

\section{Haberin Tanımı}

(h.b.r.) kökünden gelen "haber" lügatte bilmek, bir şeyi anlamak, künhüne vakıf olmak, ona nüfuz etmek anlamlarına gelmektedir. ${ }^{12}$

Haber bilginin eş anlamlısı olarak kullanılmıştır. Hatta bilgi tanımlarken "bilgi, haberdir" şeklinde tanımlar yapılmıştır. Bu anlamda "Habîr" lafzı Allah için yaygın olarak kullanılan bir lafızdır. ${ }^{13}$

Terim olarak bakıldığında Kelamcıların haberin ne olduğuyla ilgili olarak birçok tanım yaptıkları görülmektedir. Bu tanımlardan bazılarını şöyle sıralamak mümkündür.

1.Haber, doğruluk ve yanlışlık ihtimali olan kelamdır. ${ }^{14}$

kabul eden Mâturîdî ve onun gibi düşünen diğer kelamcılar için indirgemeci bir mantıkla "akılcıdır" demek onların sistemini görmemek olur. Mâturîdî’nin bilgi siteminin kaynaklarının haber, akıl, duyu olduğu ile ilgili bilgi için bk. Mâturîdî, Ebû Mansûr, Kitâbü't-Tevhit, s.11-21.

8 Bk. Mâturîdî, Kitâbü't-Tevhit, s.12; Nesefî, Tabsiratü'l-Edille, I/24.

9 Bk, Fahreddin Râzî, el-Mebahisü'l-Meşrikıyye, I/437-501; Muhassal, s. 25-37; el-Mülahhas fi'lMantık ve'l-Hikme, vr.120a-132a; Âmidî, Ebkâru'l-Efkâr fi Usûli'd-Din, I/15-26.

10 Bk. Fahreddin Râzî, el-Mahsûl fi İlmi'l-Usûl, (Thk. Muhammed Abdulkâdir Ata), Daru'l-Kütübi'l-İlmiyye, Beyrut 1999, II/93-212; Seyfeddin Âmidî, el-İhkam Fî Usuli’l-Ahkam, Beyrut 1983, II/10-145.

11 Haber, İslam Düşüncesinde sadece Kelam'da kesin bilginin kaynağı olarak kullanılmamıştır. Tarih, Mantık ve Hadis gibi birçok disiplinlerde kesin bilginin kaynağı olarak kullanılmıştır. Bu kullanımlarla ilgili ayrıntılı bilgi için bk. Erdemci, Cemalettin, "Kelam İlminde Haberin Epistemolojik Değeri,” Dinbilimleri Akademik Arastirma Dergisi, VI (2006), Sayi: 1, s.155-157.

12 Bk. Ebû Nasr İsmail b. Hammad el-Farabi el-Cevherî, es-Sthah Tâcü'l-luga ve Sthâhi'l-Arabiyye ( thk. Ahmed Abdülgafur Attar), Kahire 1982, II/641; İbn Manzur, Lisanü'l-Arab, Beyrut 1990, IV/226 vd.; Asım Efendi, Kâmus Tercümesi, Bahriye Matbaası, İstanbul 1305, II/283; Hüseyin b. Muhammed el-İsfahânî,, el-Müfredât fi Garibi’l-Kuran, İstanbul 1986, s.204.

13 Fahreddin Râzî, Mefâtihü'l-Gayb, Darü'l-Kütübü'l-İlmiye, Beyrut 2004, II/119.

14 S. Şerif Cürcânî, Tarifat, Beyrut 2002, s.83; Ayrıca bk. Nesefî, Tabsiratü'l-Edille, I/24; Gazzâlî, el-Mustasfa -Deliller ve Yorum Metodolojisi, (trc. Yunus Apaydın), Kayseri 1994, I/200 vd. 
2.Haber, kendisine doğruluk veya yanlışlık dâhil olan şeydir. Veya Haber, doğrulanabilme ve yalanlanabilme ihtimali olan şeydir. ${ }^{15}$

3.Haber, "nefiy veya ispat şekillerinden birisi ile bir durumun başka bir duruma izafe edilmesini bizzat ifade eden bir sözdür." 16

4.Haber "geçmişte meydana gelen veya gelecekte vuku bulacak bir olayı bildiren söz, mahiyeti itibarıyla doğru veya yanlış olma ihtimali bulunan söz" dür. ${ }^{17}$

Haberin ne olduğu ile ilgili yapılmış olan tanımlara bakıldığında farklı gibi görünseler de aslında birbirine yakın oldukları görülmektedir. Bu tanımlarda iki yönün öne çıktığı söylenebilir. Bu yönlerden birisi "haberin bir söz olduğu" dur. ${ }^{18}$ Diğeri ise bu "sözün" yalanlanabilme ve doğrulanabilme imkanının olmasıdır. Haber sözdür derken her türlü sözün haber olduğu anlaşılmamalıdır. Eğer bir söz doğrulanamıyor veya yalanlanamıyor ise bunu haber olarak niteleyemeyiz. Bu nedenle istifham, emir, nehiy, esef, temenni ve istirham gibi sözler haber olarak nitelendirilemezler. Fakat doğrulanabilme ve yalanlanabilme imkanı olan ispat, nefiy, medih, zem ve taaccüp gibi sözler haber olarak nitelendirilebilmektedir. ${ }^{19}$

Tanımda öne çıkan "doğrulanabilme" ve "yalanlanabilme" bize ulaşan haberin niteliği ile ilgilidir. Yani bir haber doğru olabildiği gibi yanlış da olabilir. İşte bu yönler dikkate alınarak kelamcılar tarafından haber nitelik açısından bazı kısımlara ayrılmıştır. Bu kısımları üç ana başlık altında değerlendirmek mümkündür.

1.Doğruluğu kesin olan haberler.

2.Yanlışlığı kesin olan haberler.

3.Doğruluğu ve yanlışlı̆̆ kesin olmayan haberler. ${ }^{20}$

15 Tanımlarla ilgili olarak bk. Eş'arî, Makâlâtü’l-İslâmiyyîn (thk. Helmut Ritter) Wiesbaden 1980, s.444; Kadı Ebu Bekir el-Bâkillânî, et-Temhid fi'r-Red ale'l-Mülhideti'l-Muattıla, Kahire 1947, s.160.

16 Bu tanımın Ebû Hüseyin el-Basrîye ait olduğu söylenir. Bk. Fahreddin Râzî, el-Mahsûl fi İlmi'lUsûl, II/93-96. Haber için yapılan tanımların birçok yönden eleştiri konusu olduğunu belirten Râzî, bu eleştirileri ve eleştirilere verilen cevapları ele alır. Haberin tanımlanamayacağına dair görüşünü temellendirmeye çalışır. Ayrıntılı bilgi için bk. Mustafa Bozkurt, Fahreddin Razi'de Bilgi Teorisi (Basılmamış Doktora Tezi) A.Ü.Sosyal Bilimler Ens. Ankara 2006, s.122 vd.

17 Yavuz, Y. Şevki, "Haber" mad. DİA, (Diyanet İşleri Başkanlı̆̆ı İslam Ansiklopedisi) İstanbul 1996, XIV/346.

18 "Haber" lafzı sadece konuşmada hakikat olarak kullanılır. Konuşmanın dışındaki yerlerde kullanılmaz. Konuşma ve konuşabilenlerin dışında kullanılması ancak mecazen olur. Bk. Fahreddin Râzî, el-Mahsûl, II/93.

19 Eş'arî, Makâlâtü'l-İslâmiyyîn, s.444.

20 Tasniflerle ilgili olarak bk. Eş'arî, Makâlâtü'l-ìslâmiyyîn, s.444 vd.; Abdulkâhir Bağdâdî, Usul'd-Din, Beyrut 1981, s.13; Fahreddin Râzî, el-Mahsûl; II/98; Seyfeddin Amidî, el-ihkâm fi Usuli'l-Ahkâm (thk. Seyyid Cemili) Beyrut 1983, II/12 vd. 
Doğru haber: "Vakıaya mutabık haberdir,"21 "bir şeyden olduğu gibi haber vermektir," "hakikatine dair bilgi bulunduğunda bir şeyden olduğu gibi haber vermektir,"22 "haber verenin haber verdiği şekilde gerçekleşen haberdir," ${ }^{23}$ gibi ifadelerle tanımlanmıştır. Kısaca ifade edilecek olursa, gerçekle birebir örtüşen haberler doğru haber olarak nitelendirilmektedir.

Yalan haber: "Bir şeyin hakikatinin zıddını haber vermektir," "Bilerek veya bilmeyerek bir şeyin hakikatinin zıddına haber vermektir," "Bilmeyerek bir şeyin doğruluğunun aksine haber vermektir,"24 "haber verenin haber verdiği şekilde gerçekleşmeyen haberdir," ${ }^{25}$ gibi birbirine yakın ifadelerle tanımlanmıştır. Kısaca ifade edilecek olursa, gerçeklerle birebir örtüşmeyen haberler yalan haber olarak nitelendirilmektedir.

Doğruluğu veya yanlışlığı kesin olmayan haberler ise farklı şekillerde isimlendirilerek ${ }^{26}$ daha ziyade "fıkıh usulü" ile ilgili konularda değerlendirilmiştir.

Doğru ve yanlış olarak belirtilen haberlerin tanımlarına bakıldığında öne çıkan şey verilen haberin gerçeklerle örtüşüp örtüşmediğidir. Bu gerçeklerin bilinmesinde ise haber geçerli olmayıp diğer bilgi kaynakları olan "akıl" ve "duyu" belirleyici olmaktadır. Eğer gerçeklere uygunluğu bizzat duyularla algılanmak suretiyle tespit edilmiş, veya akıl yoluyla onun kesin doğru olduğu belirlenmiş ise o zaman bu haberin doğru haber olduğu bilinmiş olur.

Bu açıdan bakıldığında haber ile vakıanın uyumu veya uyumsuzluğu yani haberin doğruluğu, diğer bilgi vasitaları ile doğrulanmaktadır. Bu durumda haberin ayrı bir bilgi kaynağı olup olmadığının sorgulanması gerekir.

\section{Bilgi Kaynağı Olarak Haber}

Haber, bilginin ayrı bir kaynağı olarak görülebilir mi? Yoksa diğer kaynaklar aynı zamanda haberi de içerisine almakta mıdır? Gibi problemlerin tartışılması gerekir. Bu konu, üzerinde farklı spekülasyonların yapılabileceği bir konudur. Çünkü haberin ne olduğu dikkate alındığında onun bir "söz" olduğunda pek farklı bir anlayış yoktur. ${ }^{27}$ Haber bir sözün aktarılması şek-

21 Mesud b. Ömer Sâduddin Taftazânî, Şerhu'l-Akaid, (Kesteli Şerhi ile beraber), İstanbul 1976, s.32.

22 Eş'arî, Ebu'l-Hasan, Makâlâtü'l-İslâmiyyîn, s.444.

23 Bă̆dâdî, Usûlü'd-Dîn, s.13.

$24 \mathrm{Bu}$ tanımlar için bk. Eş'arî, Ebu'l-Hasan, Makâlâtü’l-İslâmiyyîn, s.444.

25 Bağdâdî, Usûlü'd-Dîn, s.13.

26 Mütevassıt, Mütevakkıf vs. farklı isimlendirmelerle ilgili örnekler için krş. Bağdâdî, Usûlü'd-Dîn, s.12 vd.; Fahreddin Râzî, el-Mahsûl,II/153-169; Amidi, el-İhkam fi Usulü'l-Ahkam, II/12 vd.

27 Bk. Eş'arî, Makâlâtül'-ìslâmiyyîn, s.444; Bâkillânî, Temhid, s.160; Cürcânî, Tarifat, s.83; Nesefi, Tabsiratüll-Edille, I/24; Fahreddin Râzî,, el-Mahsûl, II/93 vd.; Yavuz, Y. Şevki, "Haber" mad. DIA, XIV/346. 
linde ele alınmaktadır. Habere bu açıdan baktığımız zaman, haber bilginin bizzat kendisi midir? Yoksa bilginin bir kaynağı mıdır? Diğer bir ifade ile, haberle yeni bir bilgi mi oluşmaktadır, yoksa oluşmuş olan bir bilginin iletilmesi mi söz konusudur? Şeklinde bir tartışma gündeme gelmektedir. Haber aslında bir başkasının edindiği bir bilginin aktarılması şeklinde ele alınabilir. Böyle bir bakış açısı ile haberin bir bilgi kaynağı olmadığı sadece oluşan bir bilginin aktarılmasından ibaret olduğu söylenebilir.

Haber denildiği zaman zorunlu olarak üç şeyden bahsedilmiş olur. Bunlardan birisi "haberi veren" diğeri "haberi işiten" bir diğeri ise "haber verilendir."

Haber veren açısından konuya baktığımızda oluşmuş olan bir bilginin aktarımı söz konusudur. Haber veren kimse bu bilgiye bilgi elde etme yollarından birisi ile ulaşmıştır. Ulaşmış olduğu bu bilgiyi de bir başkasına aktarmaktadır. Bu anlamda haber, haber veren için sadece oluşmuş olan bir bilginin aktarımıdır. Yeni bir bilginin oluşumu değildir.

Haber, işiten açısından değerlendirildiğinde, işiten için yeni bir bilgi oluşturduğu söylenebilir. İşte bu anlamda haber bilgiye kaynaklık etmektedir. Burada aktarılan bilgi duyan için bir tür bilgi elde etme vasıtasıdır. Müslüman kelamcıların haber bir tür bilgi kaynağıdır demeleri bu açıdan bir sorun oluşturmamaktadır.

Haberin tanımlarında öne çıkan "haberin bir söz olduğu" vurgusu açıldığı zaman bu sözün duyu organlarımızla işitmenin bir ürünü olduğu belirtilebilir. Bu açıdan haber aslında işitme organı ile elde edilen bir bilgidir. Bu durumda haberin ayrı bir bilgi kaynağı olup olmadığı tartış1labilir. Biz bu noktaya işaret edip, olgudan hareketle diyoruz ki, Yunan felsefesinde, İslam felsefesinde ve günümüz Batı felsefesinde haber konusu bilginin müstakil bir kaynağı olarak görülmemektedir. ${ }^{28}$ Fakat kelamcılar erken dönemden beri haberin ayrı bir bilgi kaynağı olduğunu belirtmektedirler. ${ }^{29}$

İşitilen şeyin doğru olup olmadığı o haberin niteliği ile belirlenebilir. Bu niteliği belirlemede de "akıl" aktif görev almaktadır. O zaman bilgi elde etmenin vasıtaları her ne kadar ayrı ayrı değerlendirilmiş olsa da birbirleri ile bağlantılı olduğu ve birbirlerini doğrulamada katkılarının olduğu şüp-

28 Fritz Heinemann, "Bilgi Kuram,” s. 191 vd.; A. Kadir Çüçen, Bilgi Felsefesi, s.60-64; Nicolai Hartmann, Ontolojinin Işı̆̆ında Bilgi, (trc. Harun Tepe) Ankara 1998, s.14 vd.

29 Bk. Mâturîdî , Kitabü't-Tevhid, s. 14; Nesefî, Tabsiratü'l-Edille, I/25; İbn Fûrek, Mücerredü Makalatü'l-Eş'arî (Thk. Daniel Gibnaret) Beyrut 1987, s. 17; Kâdî Abdulcebbâr, el- Muğni fi Ebvâbi't-Tevhîd ve'l-Adl, (en-Nazar ve'l-Mearif), (thk. İbrahim Medkur ve Taha Hüseyin) Kahire 1962, XII/63. 
hesizdir. ${ }^{30}$ Bu katkılar olmakla beraber her bilgi vasıtasının verdiği bilgiler, diğer kaynaklarla elde edilemeyecek niteliktedirler. ${ }^{31}$ Yani bir bilgi kaynağının verdiği bilgiyi diğer bilgi kaynakları veremez. Bu da bilgi kaynaklarının ayrı ayrı ele alınmasını gerekli kılmaktadır.

Felsefî gelenekte ayrı olarak alınmamasına rağmen Müslüman kelamcılar tarafından "haber"in müstakil bir bilgi kaynağı olarak belirtilmesinin nedeni ne olabilir? Bu konuda Mâturîdî , Nesefî gibi alimler bunun aklî bir zorunluluk olduğunu söylerler. ${ }^{32}$

Kelamcıların "haberi" bilginin müstakil bir kaynağı olarak görmelerinin nedeni olarak denilebilir ki; Dini anlayışın hemen tamamı "haber" niteliğinde olan vahye yani peygamberin haberine dayanmaktadır. Ĕger bunun verdiği bilgi kesin ve güvenilir bilgi kategorisinde görülmezse o zaman üzerine dînî düşüncenin bina edildiği temel bilgilerin güvenirliği tartışmalı hale gelir. ${ }^{33}$ Kelamcılar bu endişeyi taşıyor olmalılar ki, "haber"in tartışmasız bilgi kaynağı olduğu üzerinde ittifak halindedirler.

Haberin bilgi kaynağı olduğunu kesin olarak belirten Kelamcıların önünde önemli bir sorun olarak, her türlü haberin, kesin bilgi ifade edip etmediği konusu yer almıştır. Her türlü haberin kesin bilgi ifade edemeyeceği söylenerek, kesin bilgi ifade eden haberin "doğru haber" ile sınırlandırılması gereği üzerinde durulmuştur. Bu haber "doğru haber"(el-haberu's-sâdık) olarak isimlendirilmiştir. Kesin bilgi veren haberin de sadece bu haber olduğu belirtilmiştir. ${ }^{34}$

Doğru haberin ne olduğu konusunda her ne kadar farklı söylemler olsa da doğru haber olarak genelde "mütevâtir haber" ve "resulün haberi" belirtilmiştir. ${ }^{35}$

Bu haberlerin dışında yanlışlı̆̆ kesin olan ${ }^{36}$ ve doğruluğu veya yanlışlı$\breve{g}_{1}$ kesin olmayan ${ }^{37}$ bazı haber türlerinin de olduğu belirtilmektedir. Bu tür

30 Bilgi kaynaklarının birbirini nasıl tamamladığına örnek olarak bk. Mâturîdî , Kitabü't-Tevhid, s. 21.

31 Bk. Mâturîdî, Kitabü't-Tevhid, s. 20; Nesefî, Tabsiratü'l-Edille, I/25.

32 Mâturîdî , Kitabü't-Tevhid, s. 14; Nesefî, Tabsiratü'l-Edille, I/25.

33 Bk. Taftazânî, Şerhu'l-Akaid, İstanbul 1976, s. 30.

34 Bk. Taftazânî, Şerhu'l-Akaid , s.29; 32; Nesefî, Tabsiratü'l-Edille, I/24; Bağdâdî, Usûlü'd-Dîn, s. 12 vd.

35 Bk. Taftazânî, Şerhu'l-Akaid, s.29, 32-40.

36 Yalan olduğu kesin olan haberlerin dört kısım olduğunu belirten Râzî, bunlarla ilgili ayrıntılara geniş yer vermektedir. bk. Fahreddin Râzî, el-Mahsûl, II/133-152.

37 Doğruluğu veya yanlışlığı kesin olmayan haberlerin neler olduğu, şeriat konusunda bunların ne ifade ettiği, hangilerinin itibara alınabileceği ile ilgili ayrıntılar için bk Râzî, el-Mahsûl, II/ 153-169; Ayrıca bk. Bağdâdî, Usûlü'd-Dîn, s.12 vd. 
haberler, kesin bilgi ifade etmedikleri için genel olarak bilgi elde etmenin yolları içerisinde değerlendirilmemiştir.

Konu, "bilgi ifade eden haber" olduğundan burada "yalan haber" ve "doğruluğu veya yanlışlığı belli olmayan haber" türleri üzerinde durulmayacaktır. Kesin bilgi ifade eden haber türleri üzerinde durulacaktır. Kesin bilgi ifade eden "doğru haber" "mütevâtir haber" ve "resulün haberi" olarak iki ana başlık altında ele alınacaktır.

\section{Mütevâtir Haber}

"Tevâtür" sözlükte aralarında bir boşluk bulunmakla beraber bir şeyden sonra başka bir şeyin gelmesi anlamına gelir. Bu tabir "sonra biz peyderpey peygamberler gönderdik"38 ayetinde geçen "tetra" kelimesinden alınmıştır. $\mathrm{Bu}$, aralarında bir fetret bulunan Resuller gönderdik anlamına gelir. $\mathrm{Bu}$ konulardan bahseden kaynaklarda tevâtür "aralarında bitişiklik olmadan gelmeleri" anlamında kullanılmıştır. ${ }^{39}$

Mütevâtir haber terim olarak, "sözlerinden bilgi hâsıl olacak sayıda çoğunluğa ulaşan topluluğun haberi" ${ }^{40}$ ve "yalan üzere birleşmeleri düşünülemeyen bir topluluğun ifadeleri ile sabit olan haberdir." ${ }^{41}$ şeklinde tanımlanmaktadır.

Mütevâtir haberin kesin bilgi ifade ettiği konusunda alimlerin çoğu ittifak halindedir. Mütevâtir haber ister zamanımızda olan yeni bir şeyden isterse geçmişe dair eski şeyleri konu alan ${ }^{42}$ haber olsun fark etmez. Mütevâtir niteliğini taşıyorsa bu haber kesin bilgi ifade eder. ${ }^{43}$

Cürcânî, mütevâtir haberin tanımını sadece peygamberden gelen haberle sınırlandırarak ele alır ve peygamberden geliş şekline göre haberi "mütevâtir", "meşhur" ve "vâhit" olarak üç kısımda ele alır. ${ }^{44}$

38 Mü'minun, 23/44

39 Cevherî, es-Sihah, II/842; Fahreddin Râzî, el-Mahsûl, II/100.

40 Fahreddin Râzî, el-Mahsûl, II/100; Mütevâtir ve sadık haberin tanımları için ayrıca bakınız. Taftazânî, Şerhu'l-Akaid, s.32-35.

41 Cürcânî, Tarifat, s.83; Taftazânî, Şerhu'l-Akaid, s, 33; Yavuz, Y. Şevki, "Haber" mad. DİA, İstanbul 1996, XIV/347.

42 Râzî yeni şeylere örnek olarak, kendimizin görmediği fakat yaşadı̆̆ımız dönemde var olduğunu tevatür yoluyla bildiğimiz ülkeleri örnek verir. Eski şeylerden haber konusunda ise yaşadı̆̆1mız zamandan önce yaşamış olan devlet adamları ve geçmiş peygamberleri örnek olarak verir (bk. Fahreddin Râzî, el-Mahsûl, II/100.)

43 Fahreddin Râzî, el-Mahsûl, II/100; Nihâyetü'l-Ukul, v.22a; Taftazânî, Şerhu’l-Akaid, s, 34.

44 Bk. Cürcânî, Tarifat, s.83 vd.; Wael B. HALLAQ, "Sünni Hukuk Düşüncesinde Tümevarımsal Destekleme, Zannilik Ve Katilik” (trc. Muharrem Kılıç) Sakarya Üniversitesi İlahiyat Fakültesi Dergisi VI(2002), s.168. Cürcânî, haber konusunu onu inkar edenlerin hukuki durumları ile açıklar ve "mütevâtir haberi" inkar edenlerin kafir olacaklarını, "meşhur haberi" inkar edenin 
Berâhime ve Sümeniyye fırkaları, mütevâtir haberin kesin bilgi ifade ettiğini, kabul etmezler. ${ }^{45}$ Yine Mutezile'den Nazzâmiyye firkası, yalan üzere bir topluluğun birleşmesinin mümkün olduğunu söyleyerek, mütevâtir haberin kesin bilgi ifade etmeyeceğini belirtmektedir. ${ }^{46}$ Bazı yanılgıların olduğunu gerekçe gösteren kimseler de mütevâtir haberle elde edilen bilgilerin her zaman kesin bilgi veremeyeceğini söylerler. Bu tür yanılgıların duyu ile elde edilen bilgilerde dahi olduğu düşünülürse bunun ciddi bir itiraz olamayacağ 1 vurgulanabilir. ${ }^{47}$

Bu konuda Sümeniye'nin iki farklı yaklaşımı bulunmaktadır.

Bunlardan birisi, mütevâtir haberlerin ancak geçmişle ilgili olursa kesin bilgi ifade edeceği, günümüzde var olan şeylerle ilgili mütevâtir haberlerin ise bilgi ifade etmeyeceği, ancak güçlü bir zan ifade edeceği şeklindeki yaklaşımdır.

Diğer yaklaşım ise bunun tam tersi şeklindedir. Yani mütevâtir haberin ancak günümüzde var olan şeylerle ilgili olması durumunda bilgi ifade edebileceği, geçmişle ilgili olarak bilgi ifade etmeyeceği tarzındadır. Bu iki farklı görüş ile ilgili olarak Sünni düşüncede buna itiraz olarak şu açıklama getirilir. Kendisini görmediğimiz fakat şu anda var olan beldeler ve geçmişte yaşayan şahıslarla ilgili kendimizde öyle kesin bir bilgi oluşur ki, bize göre bu bilgi ile bizzat görerek elde ettiğimiz bilgi arasında hiç bir fark kalmaz. Bu haberi inkâr eden tıpkı görünen şeyleri inkâr eden gibidir. Mütevâtir haber bizzat görünen şeylerle ilgili elde ettiğimiz kesin bilgiler gibi kesin bilgi ifade eder. ${ }^{48}$

Bir şey hakkında verilen haber, eğer mütevâtir bir haber niteliğini taş1yor ise, cumhura ${ }^{49}$ göre bu haber kesin bilgi ifade eder. Bazı farklı yakla-

durumunun kesin olmadığı fakat bu kimseler için doğru olanın kafir olmalarıdır. "Vahit haber" için ise inkar edenlerinin ittifakla kafir sayılmayacağı şeklinde bir hüküm açıklarlar bk. Cürcânî, Tarifat, s.83. Bağdâdî de haberi bilgi konusunda işlerken haberin, mütevâtir, ahad ve bu iki haber arasında olan "mütevassit" haber olarak üç kısımda ele alır. Haber konusunu peygamberden gelen haberle sınırlı tutan Bağdâdî, daha ziyade hukuki açıdan haberlerle amel edilip edilmeyeceği ve bu şekilde gelen haberleri inkar eden kimselerin hukuki durumu ile ilgili bilgiler verir. Bk. Bağdâdî, Usûlü'd-Dîn, s.12 vd. ahad haberin kısımları ve ahad haberle sabit olan hükümlerle ilgili ayrıntılı bilgi için bk. Bağdâdî, Usûlü'd-Dîn, s.13; Gazzâlî, el-Mustasfa (trc. Yunus Apaydin), I/218- vd.

45 Bk. Nesefî, Tabsiratü'l-Edille, I/25; Bağdâdî, Usûli’d-Dîn, s.11.

46 Bk. Bağdâdî, Usûli'd-Dîn, s.11.

47 Bk. Bağdâdî, Usûli'd-Dîn, s.12.

48 Sümeniyenin yaklaşımlarının ayrıntıları için bk. Fahreddin Râzî, el-Mahsûl, II/101.

49 Cumhur, aynı kararı veya hükmü veren âlimlerin çoğunluğu anlamındadır. Bk. Büyük Lügat(Heyet tarafından hazırlanan, Osmanlıca Türkçe Ansiklopedik Büyük Lügat), Türdav Yay. İstanbul 1990, s.163. 
şımlar ${ }^{50}$ olmakla beraber, Kelamcıların hemen tamamına yakını mütevâtir haberin doğru bilgi için kaynaklık edeceği görüşünü savundukları görülmektedir. ${ }^{51}$

Haberin mütevâtir olması için geçerli olan şartlar, ${ }^{52}$ ya haberi dinleyen kimselerle ilgili olur ya da haber veren kimselerle ilgili olur. Haberi dinleyen kimselerle ilgili şartlar ise ikidir.

1.Haberi duyan kimsenin o haberi daha önceden zorunlu olarak bilmemesi gerekir. Çünkü bilinen bir şeyin bilinmesi "hâsıl olanın tekrar tahsili" olacağından bu muhaldir. Aynen bunun gibi hâsıl olana benzeyenin ve onu kuvvetlendirenin de tekrar bilinmesi yine muhaldir. Örneğin, "nefiy ve ispat'ın her ikisi aynı anda bulunamaz, yine aynı anda her ikisinin olmamas1 da imkânsızdır" şeklinde bilgi oluştuktan sonra bu hükümle ilgili haberin verilmiş olmasının o ilk oluşan bilgiye bir katkısı olmaz. Çünkü bu bilgi zaten o kimsede bulunmakta idi. Haberin bilgi ifade etmesi, haber verilen kimsenin o haberi önceden bilmiyor olması ile anlam kazanmaktadır. ${ }^{53}$

2.Şerif Murtaza'ya göre, haberi işiten kimsenin, o haberin reddedilmesine dair bir önyargısının, şüphesinin ve inancının bulunmaması gerekir. Şerif Murtaza, haberi işiten kimse için bunu şart koşmasının nedeni olarak şunu görür. Hz. Ali'nin imameti ile ilgili nas olduğuna dair mütevâtir haber vardır. Bu haber mütevâtir olmasına rağmen bazı kimseler için bilgi ifade etmemektedir. Bilgi ifade etmemesinin nedeni ise işitenlerin bazısının bir şüpheden dolayı bu haberin nefyedilmesine olan inançlarıdır. ${ }^{54}$

Şerif Murtaza'nın bu deliline "mütevâtir haberin sonucunda bilginin oluşumu, eğer bir geleneğe bağlı olarak gerçekleşiyorsa, bu geleneğin verdiği farklı bilgilere göre, bilginin oluşumu da farklılık arz eder. Ĕğer haberi işiten kimsede gelenekten gelen ve yeni duyduğu haberin aksine bir inanç yoksa mütevâtir haberle kendisine ulaşan haber bilgi ifade eder. Eğer mütevâtir haberin getirdiği hükme zit bir inanç kendisinde önceden bir gele-

50 Mutezileden Ebu'l- Hüseyin el-Basri ve Kâbî’nin, yine İmam el-Haremeyn ve Gazzâlî’nin bu görüşe muhalif oldukları belirtilir. Şerif Murtaza gibi, mütevâtir haberin kesin bilgi ifade edip etmeyeceği konusunda herhangi bir tercihte bulunmayıp bu konuda çekimser kalanların da varlığından bahsedilir. Bu iddiaları kendi eserlerinde doğrulama fırsatı bulamadığımızdan sadece iddia olarak almayı uygun bulduk. Bk. Fahreddin Râzî, el-Mahsûl, II/102; Amidî, elihkâm fi Usuli'l-Ahkâm, II/28.

51 Mütevâtir haberin kesin bilgi ifade etmeyeceği ile ilgili itirazlar ve bu itirazlara verilen cevapların ayrıntıları için bk. Fahreddin Râzî, el-Mahsûl, II/103-115.

52 Bu şarlarla ilgili olarak bk. Fahreddin Râzî, el-Mahsûl, II116 vd.; Krş. Gazzâlî, el-Mustasfa (trc. Yunus Apaydin), I/203-211.

53 Bk. Fahreddin Râzî, el-Mahsûl, II/116.

54 Fahreddin Râzî, el-Mahsûl, II/116. 
nek olarak bulunuyor ise, o zaman mütevâtir haberin getirmiş olduğu hükmün bilgisel bir değeri yoktur" diyerek karşı çıkılmıştır. ${ }^{55}$

Burada karşı çıkılan husus Şerif Murtaza'nın böyle bir inancın bulunmamasını şart olarak öne sürmüş olmasıdır. Çünkü böyle bir geleneğin olmaması imkânsızdır. Yani haber mütevâtir bir haber niteliğinde de olsa eğer geçmişten gelen inançlar ile örtüşmüyorsa bunun bilgisel değer ifade etmesinde bazı güçlükler yaşanmaktadır. Burada sorgulanması gereken önceden bir inancın varlığ veya yokluğu olmayıp o inancın nasıl bir nitelik taşıdığı olmalıdır. Eğer dinin temelini oluşturan Kur'an ayetlerine uymayan fakat Kur'an dişı kültürlerle oluşan bazı inançlar bulunur, bu inançlar da mütevâtir niteliğindeki haberlerle çelişir ise, o zaman bu inançların sorgulanması ve problemlerinin ortaya konulması gerekir. Bunun aksi de önemlidir. Yani Kur'an bütünlüğüne uygun olan bir inanç geleneksel olarak toplumda yer etmiş ise ve mütevâtir niteliğinde de bir haber ile ters düşmekte ise o zaman bu haberin mütevâtir olup olmadığı konusunun tekrar sorgulanarak yeniden değerlendirilmesi kaçınılmaz olacaktır.

Kendimizin bizzat görüp müşahede etmediği bir olay veya yer hakkında, mütevâtir bir haber varken bir kimse çıkıp da mütevâtir olarak bize ulaşan haberin yanlış olduğunu söylerse, bizim mütevâtir haberi bırakıp bu kimsenin haberini kabul etmemiz doğru olmaz. Bu durumda mütevâtir habere itibar etmemiz daha uygun bir tutum olur. ${ }^{56}$

Haberi duyan kimselerle ilgili bunlar söylendikten sonra haber verenlerle ilgili de bazı konular üzerinde durulur. Çünkü haber konusunda, hem haberi işitenler hem de haberi verenler önem arz eder. Hatta haber verenlerle ilgili şartlar mütevâtir haberin ne olması gerektiği konusunda daha da önemli olmaktadır. Çünkü asıl doğru bilgi haber verenlerde bizzat gerçekleşmektedir. Haberi duyanlar, önceden gerçekleşen bir bilginin aktarımı ile karşı karşıyadırlar. Bu aktarım öyle inandırıcı olmalı ki, kişi bizzat kendisinin duyular veya akıl yoluyla elde ettiği bilgi gibi olduğuna inanmalıdır.

Haber verenlerde olması gereken şartlar olarak üzerinde durulan özellikler şunlardır:

1.Haber verenlerin o şeyi haber vermek zorunda olmaları gerekir. Eğer vermek zorunda olmadıkları bir haber olursa, o habere bazı şeylerin karıştırılması ihtimalinden dolayı, bilgi ifade etmez. Bu nedenle Müslümanlar Hz. Muhammed'in nübüvveti ile ilgili bilgileri Yahudilere haber verdiler fakat bu Yahudiler için bir bilgi ifade etmedi.

55 Fahreddin Râzî, el-Mahsûl, II/116.

56 Fahreddin Râzî, el-Mahsûl, II/116-117. 
2.Bir haberin mütevâtir haber olması için haber verenlerin belli sayıda olması gerekir denilmiştir. Haber verenlerin verdikleri haberin mütevâtir haber olması için adetlerinin kaç kişi olması konusunda değişik görüşler ileri sürülmüştür. ${ }^{57}$

Bu konuda haber verenlerin en az dört veya beş veya yedi vs. kişi olması gerekir şeklinde birtakım adetler belirtilmiştir. Bunun formüle edilmesinde bazı ayetlerde geçen sayısal ifadeler ${ }^{58}$ veya bazı olaylarda ${ }^{59}$ geçen sayılar esas alınarak mütevâtir haberde çoğunluğun bu sayı olduğu üzerinde durulmuştur. ${ }^{60}$ Bir çok kelamcı mütevâtir haber için herhangi bir sayı belirtilmesinin doğru olmayacağını söylerler. Bu konuda sayı olarak hangi sayı söylenirse söylensin o sayıya dahil olan kimselerin yalan söylemeyecekleri aklen kesin değildir. Hatta bu sayısal miktara ulaşan kimseler yalan üzere birleşebilirler. Bu sayının bir fazla veya bir eksik olmasının da önemi yok, dört kişi yalan üzere birleşebiliyorsa beş kişide birleşebilir. Bu nedenle mütevâtir haber de asıl olan yalan üzere ittifak etmeleri aklen mümkün olmayan kimselerin ittifak etmesidir. ${ }^{61}$ Bunların adetleri önemli değildir. Önemli olan haber verenlerin durumunun haber alan kimseleri ikna edecek şekilde olmasıdır. ${ }^{62}$

Bazı haberler vardır ki haberde geçen konu için mütevâtir olmadığından bilgi ifade etmeyebilir, fakat anlam açısından mütevâtir haber olarak nitelendirilebilir. Örneğin bir kimse Hatem isminde bir zatın on tane köle azat ettiğini haber verse, bir başka kimse Hatem'in, beş tane deve hibe ettiğini söylese, bir başka kimse de Hatem'in yirmi adet elbise hibe ettiğini söylese, bu haberlerin her biri mütevâtir haber niteliğinde olmadığı için kesin bilgi ifade etmez. Fakat bütün bu haberlerin bir kişi üzerinde yoğunlaşmış

57 Haberin şartları ile ilgili olarak bak. Fahreddin Râzî, el-Mahsûl, II/ 116 vd.; Gazzâlî, elMustasfa (trc. Yunus Apaydın), I/203-211.

58 Mütevâtir haber de esas alınan sayılar konusunda ayetleri delil olarak alanlar şu ayetlerde geçen sayıların mütevâtir haberde esas teşkil ettiğini belirtirler. Maide, 5/12 de geçen "on iki" sayısı; Enfal, 8/65 de geçen "yirmi" sayısı; Enfal 8/64 "Ey peygamber! Sana ve sana uyan müminlere Allah yeter" ayetinde Peygambere uyanların adedi Hz. Ömer’in Müslüman oluşu ile kırk kişiye ulaşmıştı, bu ayette bunun üzerine gelmiştir şeklindeki rivayet esas alınarak "kırk" denilmiş; A'raf 7/155, ayetinde geçen "yetmiş" sayısı, bk. Fahreddin Râzî, el-Mahsûl, II/119

59 Örneğin Bedir Ashabının adedi olan üç yüz on civarındaki bir sayı, mütevâtir haberde esas alınır demişler, yine "Rıdvan Biatindeki" sayı esas alınır diyenler olmuştur. Bk. Fahreddin Râzî, el-Mahsûl, II/120

60 Mütevâtir haber konusunda öne sürülen sayılar ve bununla ilgili değerlendirmeler için bk. Gazzâlî, el-Mustasfa (trc. Yunus Apaydın), I/204 vd.

61 Taftazânî, Şehu'l-Akaid, s. 33-34; Fahreddin Râzî, el-Mahsûl, II/120; Yavuz, Y. Şevki, "Haber" mad. DIA, XIV/347.

62 Mütevâtir haber konusunda adetler ve bunlarla ilgili ayrıntılı bilgi için bk. Râzî, el-Mahsûl, II/ 120. 
olması anlam bakımından mütevâtir olan bir habere delalet eder ve kesin bilgi verir. O haber de şüphesiz Hatem ismindeki şahsın cömert bir kimse oluşudur. Çünkü verilen haberlerin her biri, anlam bakımından cömertlik konusunda birleşmektedir. Hakkında bu kadar bilgi verilen bir kimsenin ne yaptığ $\breve{1}_{1}$ konusunda kesin bir bilgiye ulaşılmamakla beraber onun cömert olduğu ile ilgili olarak kesin bilgi bizde olușmuș olur. ${ }^{63}$

Bir haberin doğru haber olarak nitelendirilebilmesi için mutlaka mütevâtir haber olma zorunluluğu yoktur. Daha doğrusu, doğru haberin tek seçeneği mütevâtir haber değildir. Mütevâtir olması doğru olmasının bir göstergesidir fakat mütevâtir haberin dışında da doğru olan haber türleri vardır. ${ }^{64}$

\section{Resulün Haberi}

Haber-i Resul, Allah'ın insanlara mesajlarını iletmek için gönderdiği ve elçiliği mucize ile sabit olan zatın vermiş olduğu bilgidir. ${ }^{65}$

Müslüman kelamcılar peygamber olan zatın vermiş olduğu bilginin kesin doğru bilgi olduğunu aklî bir çıarım olarak görür ve peygamberin aklen yalan söylememesi gerektiğini kabul eder. ${ }^{66}$ Fakat tartışma, peygamberin verdiği haberin doğruluğu veya yanlışlı̆̆ üzerinde olmayıp bir kimsenin peygamber olup olmadığı konusunda yoğunlaşmıştır. Kelamcılar, peygamber olduğunu iddia eden kimsenin peygamber olduğunu mucize ile ispatlaması gerektiğini söylerler. ${ }^{67} \mathrm{Bu}$ ispatlamada iddiasını doğrulamak için "hâriku'l-âde" olarak yapılması imkansız olan bir şeyi yapması gerekmektedir. Bunu yapmak suretiyle insanlara peygamber olduğunu ispatlarsa ondan sonra Allah'tan aldığını söylediği haberler tartışmasız olarak doğru haber kategorisine girer. ${ }^{68}$

İslam Düşüncesinde Resulün haberinin doğruluğu konusunda farklı deliller ileri sürülerek konu genişçe işlenmiştir. Gazzâlî, peygamberin elinde

63 Fahreddin Râzî, el-Mahsûl, II/120-121; Gazzâlî, el İktisad fi'l-itikad, Ankara 1962, s.209.

64 Örneğin F. Râzî Mütevâtir haber ve "Resulün haberi” dışında bazı haberler daha zikreder. Fakat bunların niteliklerine baktığımız zaman ya mütevâtir haber niteliğinde ya da Resulün haberi niteliğinde olduğunu görüyoruz. Geniş bilgi için bk. Fahreddin Râzî, el-Mahsûl, II/127.

65 Nesefi, Tabsiratü'l-Edille, I/27; Taftazânî, Şehu'l-Akaid, s. 35- 36; Yavuz, Y. Şevki, "Haber" mad. DIA, XIV/348.

66 Bu konuda ayrıntılı bilgi için bk. Mâturîdî , Kitâbü't-Tevhîd, s.227 vd.

67 Bk. Mâturîdî , Kitâbü't-Tevhîd, s.291 vd; Nesefî, Tabsiratü'l-Edille, II/38 vd.; İbn Fûrek, Mücerredetü Makâlâtü'l-Eşar,î s.176.

68 Kelamcılar bir zatın peygamber olduğunu mucizenin dışında ispat eden başka ispat şekillerinden de bahsederler. Konu farklı olduğundan bu ayrıntılara girmeyeceğiz. Bu konuda ayrıntılı bilgi için bk. Mâturîdî , Kitâbü't-Tevhîd, s.291vd., 314-332.; Nesefî, Tabsiratü'l-Edille, II/38 vd.; İbn Fûrek, Mücerredetü Makâlâtül'-Eşarî, s.176 vd. 
mucizenin gerçekleşmesini, bunun delili olarak gösterir. ${ }^{69}$ Peygamberden başkasının mucize göstermesinin imkânsızlığını belirten Gazâlî eğer peygamberin dışında yalancı bir kimse mucize göstermiş olsa idi o zaman peygamberinin doğruluğunu tasdik etme konusunda Allah acze düşerdi. Fakat Allah, peygamberini doğrulama konusunda aciz değildir görüşündedir. ${ }^{70}$

Gazzâlî̀nin görüşünü zikreden F. Râzî, bu görüşe bazı itirazların yapıldığını belirtir. Allah yalancı bir kimsenin elinde de mucize gerçekleştirmeye güç yetiremez mi? Hem yalancının elinde mucizeyi gerçekleştirip hem de Resulünün haberini doğrulayamaz mi? Peki, bu aciz olma konusunda birini kabul edip birini kabul etmemenin kendisi, Allah'a bir acizlik isnat etmek değil midir? Bu ve bunun gibi pek çok soru ile Gazzâlî’nin görüşüne karşı çıkanlar olmuştur. ${ }^{71}$

F. Râzî, Gazzâlî̀ye yapılan bu tür itirazlara katılmayarak bunların anlamsız itirazlar olduğunu söyler. Bir şeyin mümkün olmaması acziyeti gerektirmez. Acziyet ancak olması mümkün olan şeylerde söz konusu olabilir. Eğer olma imkânı olmayan bir şey ise, bunu bir failin yapmaması onun için bir acizlik göstergesi olamaz. Mesela Allah kendisi gibi birini yaratmaktan acizdir şeklinde bir şeyle vasıflandırmak yanlış olur. Bu ifadelerle Gazzâlî̀ye yapılan itirazları reddeden F. Râzî resulün haberi konusunda kendi görüşünü şöyle belirtir. ${ }^{72}$

Bir kimse Allah'ın elçisi olduğu iddiasında bulunsa ve bu iddiasını ispatlamak için mucize getirse, eğer getirmiş olduğu mucize, iddia ettiği konu ile ilgili olarak kendisini doğruluyor ise bu onun elçi olduğunu gösterir. Eğer getirmiş olduğu mucize iddia ettiği şeyi doğrulamıyorsa elçi sayılmaz. Ayrıca mucizenin istenen her konuda, istenilen şeye uygun olarak, kendisini doğrulayan biçimde gerçekleşmesi gerekir. Eğer bazı konuda mucize getirir bazı konuda getiremez ise veya getirdiği mucize kendi iddiası doğrultusunda gerçekleşmez ise o zaman bu kimsenin elçi olması imkânsız olur. Bu kimsenin söylediği doğru şeyler olabilir, fakat resulün haberinde olduğu gibi kesin bilgi ifade etmez. O kimsenin haberi diğer haber ölçülerine göre değerlendirilir. Eğer bir kimsenin resul olduğu kesin olarak biliniyor ise işte o kimsenin vermiş olduğu haberler doğru haberdir, kesin bilgi ifade ederler. ${ }^{73}$

69 Bk. Gazzâlî, el-ikktisad fi'l-ittikad, s.204 vd.

70 Fahreddin Râzî, el-Mahsûl, II/126

71 Bk. Fahreddin Râzî, el-Mahsûl, II/126

72 Fahreddin Râzî, el-Mahsûl, II/126 vd.

73 Fahreddin Râzî, el-Mahsûl, II/126. 
İslam filozofları da "vahyi" ayrı bir bilgi kaynağı olarak ele alırlar ve doğru bilginin kaynakları arasında görürler. ${ }^{74}$ Fakat onlar "vahyi" haber şeklinde almayıp "faal aklın mütahayyileye gönderdiği bilgi" şeklinde "kalbi bir sezgi" olarak görürler. ${ }^{75} \mathrm{Bu}$ anlamda vahyi değerlendirip, bilginin kaynaklarında ona yer verirler.

Peygambere vahyedilen bilgilerin peygamber aracıllı̆̆ ile bizlere ulaşmış olması ister "haber-i resul" olarak ele alınsın isterse İslam filozoflarının belirttiği gibi "kalbî bir sezgi" olarak ele alınsın kesin bilginin kaynağı olmasında İslam düşüncesinde bir farkl1lık yoktur. Fakat peygamberin vahiy dişında bildirdiklerine gelince işte bunların kesin bilgi ifade eden "haber-i resul" kategorisinde değerlendirilip değerlendirilemeyeceği tartışılmalidir.

Vahiy dışındaki "resulün haberi" ele alındığı zaman, burada iki hususa özellikle dikkat çekmek gerekir. Bunlardan birisi, Resulün kendisinin verdiği haber ve bunu bizzat resulden duyan kimse için ne ifade ettiğidir. Diğeri ise peygamberden bizzat duyulmayıp, peygamberden duyduğunu iddia eden kimselerin aktarımı ile oluşan haberlerdir.

Mâturîdî, Hz. Peygamberin haberi bize, yanılmaları ve yalan söylemeleri mümkün olan kimseler tarafından ulaştırıldığı için bu konuda dikkatli olunması gerektiğini belirtir. Böyle bir rivayet doğru da olabilir yalan da olabilir. Bu oluşturulan haberin yalan olduğuna hiçbir şekilde ihtimal verilmiyorsa ve doğru olduğu konusunda kesin kanaat oluşmuş ise, bu haberi alan kimsenin yapması gereken o haberi aynen Hz. Peygamberin kendisinden işitmiş gibi telakki etmesidir der. Bunun da Hz. Peygamberden mütevâtir şeklinde gelen haber olduğunu söyler. ${ }^{76}$

Haber konusunu peygamberden gelen haberle sınırlı tutan Bağdâdî, daha ziyade hukuki açıdan haberlerle amel edilip edilmeyeceği ve bu şekilde gelen haberleri inkar eden kimselerin hukuki durumu ile ilgili bilgiler verir. $^{77}$

74 Aydın, Fârâbî̀de Bilgi Teorisi, s.140-151; Peker, İbn Sina'nın Epistemolojisi, s.143.

75 Aydın, Fârâbî'de Bilgi Teorisi, s.140-151; İbn Sina'ya göre, faal akıldan feyezan eden bilgilerin tamamını ya aniden yada buna yakın bir zamanda doğrudan doğruya elde etmektedir. Bu elde ettiği bilgi "vahiy" dir. Normal insanın bilgisi ise parça parça ve belirli bir akıl yürütmenin sonucu olarak ortaya çıkmış önermelerden ibarettir. İnsan bunu uzun bir zaman diliminde ortaya koyduğu duyusal ve zihinsel çabaların neticesinde elde etmektedir. Bu da felsefi ya da akli bilgidir. Peker, İbn Sina'nun Epistemolojisi, s.143.

76 Mâturî̀î , Kitâbü't-Tevhîd, s.14

77 Bk. Bağdâdî, Usûlü'd-Dîn, s.12 vd. ahad haberin kısımları ve ahad haberle sabit olan hükümlerle ilgili ayrıntılı bilgi için bk. Bağdâdî, Usûlü'd-Dîn, s.13. 
Cürcânî, haber konusunu onu inkar edenlerin hukuki durumları ile açıklar ve aynen Bağdadi'nin yaptığ gibi haberleri Peygamberden verilen haberle sınırlandırır. Bu anlamda Peygamberden verilen "mütevâtir haberi" inkar edenlerin kafir olacaklarını, "meşhur haberi" inkar edenin durumunun kesin olmadığı fakat bu kimseler için doğru olanın kafir olmalarıdır. "Vahit haber" için ise inkar edenlerinin ittifakla kafir sayılmayacağı şeklinde bir hüküm açıklarlar. ${ }^{78}$

Resulden verilen haber, haber kriterlerine göre değerlendirilir. Eğer mütevâtir bir haber ise onun peygambere aidiyeti konusunda kesinlik ifade eder. Bu haber vahyin dışında bir haber ise o zaman bunun bilgi teorisi açısından kesin bilgi ifade edeceğini söylemek mümkün değildir. Çünkü kesin bilgi ifade eden "resulün haberi" olup "resulden haber" değildir. "Resulün haberi" ile resulden haberi" birbirine karıştırmamak gerekir. Çünkü resulün haberi Allah tarafından denetlenmekte ve gerektiğinde müdahale edilmekte idi. ${ }^{79}$ Gelenekte böyle bir ayrımın yapıldığını söylemek pek mümkün görünmemektedir. ${ }^{80}$ Peygambere ait olduğu kesin olan vahiy dışındaki sözlerin ve sünnetin ne şekilde değerlendirileceği ve Müslümanlar için ne ifade ettiği ayrıca tartışılmalıdır. ${ }^{81}$

\section{Sonuç}

Felsefi gelenekte bilginin kaynağı konusunda yapılan tartışmalara baktığ1mız zaman, tartışmaların genelde akıl ve duyu ekseninde yoğunlaştığını görürüz. Günümüz felsefesinde de bilginin kaynağının ne olduğu konusu yine bu iki temel üzerinde tartışılmaktadır. Müslüman kelamcılar bu genel eğilimi aşarak, bilginin kaynağı konusunda bir üçüncü kaynak olarak "haberi" gündeme getirirler. Yunan felsefesinde, İslam felsefesinde ve günümüz Batı felsefesinde bilginin kaynağı konusunda "haber" ayrı bir kaynak olarak alınmamıştır. Genelde duyu ve akıl üzerinde durulmuştur. Fakat kelamcılar, bilgi ile ilgili konuları işlerken bilginin kaynağının neler olduğunu tartıştıkları yerde "haberi" ayrı bir kaynak olarak belirtmişlerdir.

78 bk. Cürcânî, Tarifat, s.83.

79 Hz.Peygambere gönderilen vahyin Allah tarafından denetlendiği ve Peygamberin ona bir şey katamayacağ 1 ile ilgili Ku'an ayeti, "Kur'an alemlerin Rabbinden indirilmiștir. Eğer Muhammed, bize karşı ona bazı şeyler katmış olsaydı. Biz onu kuvvetle yakalardık, sonra onun şah damarını koparırdık. Hiçbiriniz de onu koruyamazdınız" (Hakka 68/43-47) Krş. Yunus 10/15; Sa'd 38/86-87; Zümer 39/11-14; Şura 42/24; Ahkaf 46/8-9.

80 Örnek için bk. Bağdâdî, Usûlü’d-Dîn, s.12 vd; Cürcânî, Tarifat, s.83.

$81 \mathrm{~Hz}$. Peygamberin vahiy dışındaki sözlerinin ve sünnetinin müminler için ne ifade ettiği ve nasıl değerlendirilmesi gerektiğ̣i bu konunun dışında olduğundan bunun ayrıntılarına girilmeyecektir. Bu konuda geleneksel anlayış ve bu anlayışa getirilen eleştiriler ve öneriler ile ilgili ayrıntılı bilgi için bk. Ahmet Akbulut, Nübüvvet Meselesi Üzerine, Ankara 1992, s.83-98. 
Bilginin kaynakları konusunda Kelamcılar indirgemeci olmayıp çoğulcu bir yaklaşım sergilemişlerdir. Bilginin kaynağının teke indirilemeyeceği temel tezini savunmuşlardır. Bilgi kaynakları olarak duyu ve aklın yanı sıra haberi de ayrı bir bilgi kaynağı olarak almışlardır. Kelamcıların genel yönteminden farklı olarak Memzüc dönemin bazı Eş'arî Kelamcıları bilgi konusunu filozofların ele alış tarzı ile ele alırlar. Bir yöntem olarak, bilgi konusunu işledikleri eserlerinde bilginin kaynağı olarak duyu ve akıldan bahsederler, habere yer vermezler. Fakat aynı Kelamcilar usul ile ilgili eserlerinde ise haber konusunu ayrı bir başlık altında ele alıp, kesinlikle doğru bilginin kaynağı olduğunu söylerler.

Kelamcılar, "ilâhi vahyi" de içermesi açısından "habere" epistemolojilerinde önemli bir yer verirler. İslam dininin temelleri ilahî vahye dayanmaktadır. Eğer ilahî vahyin doğru bilgi ifade etmesinde her hangi bir şüphe olacak olursa o zaman dinin üzerine inşa edildiği şeyler kesin doğru olamayacağından problemli olacaktır. Bu temel endişeden hareketle Müslüman kelamcılar "ilahî vahyi" de içine alan "haber" konusunu bilginin ayrı bir kaynağı olarak ele alırlar ve eğer haberin doğruluğu kesin ise bu haberin de kesin bilgi ifade edeceğini belirtirler.

Kendisine "haber-i sadık" dedikleri doğru haber kategorisine hangi haberlerin gireceği konusunda değişik sinıflandırmalar yapılmakla beraber genel olarak "mütevâtir" ve "resulün haberi" kelamcılar tarafından doğru haberin kısımları olarak benimsenmiştir.

Mütevâtir haber, genelde yalan üzere birleşmeleri aklen muhal bir topluluğun verdiği haber şeklinde kabul görmüştür. Bu haberi veren kimselerin sayısı konusunda bazı rakamlar belirtilmekle beraber hakim olan anlayış sayı ve adedin önemli olmadığı şeklindedir.

Hz. Peygamberin vahiy olarak aktardığı haberler Müslüman kelamcılar tarafından tartışmasız kesin bilgi olarak kabul edilmiştir. Fakat Hz. Peygamber döneminde yazılmasına pek müsaade edilmeyen "hadislerin" sonraki dönemlerde rivayetlere bağlı olarak yazıya geçirilmesi onun Hz. Peygambere aidiyeti konusunda bazı sorunları beraberinde getirmiştir. Bazı siyasi olayların ve yapılan iç çekişmelerin etkisi ile hadislere peygambere ait olmayan bazı metinlerin dahil edilebilmiş olacağı endişesi yaşanmıştır. $\mathrm{Bu}$ endişelerle hadis rivayeti konusunda birçok kriter getirilmiştir. Bu kriterler daha ziyade rivayet edenlerle ilgili geliştirilmiştir.

Hadisleri rivayet edenlerin durumuna göre "mütevâtir," "ahad," "meşhur" gibi bazı sınıflandırmalar yapılmıştır. Bu rivayetlerin kelamda ve fikıhta nasıl değerlendirileceği ile ilgili bazı görüşler ortaya konulmuştur. Fakat Hz. Peygambere ait olduğunda şüphe olmayan vahiy dışı ifadelerin, bilgi 
teorisi açısından kesin bilgi ifade edip etmediği konusunda bir tartışmaya rastlamadık. Bu, irdelenmesi ve netleştirilmesi gereken bir konudur. "Peygamberin haberi" ile vahyin kastedildiği söylenebilir. Diğer rivayetler ise "peygamberin haberi" olarak değil "peygamberden haber" olarak isimlendirilmelidir. 